\section{Intersections}

Canadian Journal of Music

Revue canadienne de musique
Intersections CANADIAN JOURAL OF MUSIO

\title{
The Power of Stories: Canadian Music Scholarship's Narratives and Counter-Narratives
}

\section{Beverley Diamond}

Volume 33, numéro 2, 2013

Musical Perspectives, People, and Places: Essays in Honour of Carl Morey

URI : https://id.erudit.org/iderudit/1032701ar

DOI : https://doi.org/10.7202/1032701ar

Aller au sommaire du numéro

Éditeur(s)

Canadian University Music Society / Société de musique des universités canadiennes

ISSN

1911-0146 (imprimé)

1918-512X (numérique)

Découvrir la revue

Citer cet article

Diamond, B. (2013). The Power of Stories: Canadian Music Scholarship's Narratives and Counter-Narratives. Intersections, 33(2), 155-165.

https://doi.org/10.7202/1032701ar
Résumé de l'article

Cet article propose une réflexion sur les transformations des récits des chercheurs en musique canadienne au cours des années 1980, transformations qui ont généralement mené à un récit davantage centré sur les diversités. On y examine comment les politiques gouvernementales, la construction d'institutions universitaires, l'augmentation de l'interdisciplinarité, les nouveaux modèles d'expérience individuelle et collective et de nouveaux discours identitaires régionaux et nationaux ont joué un rôle dans ces transformations. On avance que les Canadiens sont sans doute particulièrement bien placés pour montrer la voie dans l'étude de la façon dont plusieurs récits et « esthétiques souveraines » peuvent coexister.
Copyright @ C Canadian University Music Society / Société de musique des universités canadiennes, 2013
Ce document est protégé par la loi sur le droit d'auteur. L'utilisation des services d’Érudit (y compris la reproduction) est assujettie à sa politique d'utilisation que vous pouvez consulter en ligne.

https://apropos.erudit.org/fr/usagers/politique-dutilisation/ 


\title{
THE POWER OF STORIES: CANADIAN MUSIC SCHOLARSHIP'S NARRATIVES AND COUNTER-NARRATIVES
}

\author{
Beverley Diamond
}

When my children were born, I wanted to bathe them in the oral traditions of the Nishnaabeg so they would grow up grounded in their own

sense of being and take their space in a world often intent on erasing Indigenous people. I wanted the beauty of Nishnaabeg culture to protect them from the harshness that is so often our reality. -L. Simpson 2013

When the remarkable Anishnaabeg writer and scholar Leanne Simpson describes the meaning of stories, she sees them as surrounding, teaching, and comforting the next generation, offering protection against the harshness of colonial inequities that continue to have an impact on Aboriginal people.

Decades ago, academics would likely deem "stories" to be fiction, quite different from evidence-based research. But the way we frame research questions, the decisions we make about what counts as evidence, the motives we have for studying one thing and not another, and who exactly "we" are all lead me to think about "narratives"-the more academic version of "stories" what extent do the methods of observation and interpretation in the study of music in Canadian society prepare individuals or groups to "take their space in [the] world"? What do we look for as observers of this world, and which subset of people in Canada find "their own sense of being" in what is written? Does our work seek to "protect" anyone or anything? How can we understand the roles that expressive culture plays in creating "erasures"-those about which Simpson writes and others? How have some processes of "nationalization" created deeply embedded and naturalized structures of meaning with limited and often uncomfortable colonialist bases?

As we honour Carl Morey, it is appropriate to consider how we frame something we identify as "Canadian music." Morey's own extensive knowledge and lifelong engagement with the subject, reflected in part by his all-important bibliographic guide of 1997, Music in Canada: A Research and Information Guide, is a significant contribution to such a conversation. The narratives of Canadian

1 I use "stories" here not to reference a fictional account of the world that could be imaginary rather than "true," but rather to note that all stories are rooted in keen observation. My juxtaposition of story and academic narrative reflects my support for recent Indigenous theory (see Simpson and Smith 2014), which argues that "theory" in the sense of deep thinking about the issues that matter in our lives is not separate from practice, nor restricted to the academy. 
music scholarship are malleable and subject to reinvention, written by scholars attentive to particular aspects of sonic culture as lived in different locales. How have they shifted and diversified in recent decades? In 1988, I had a basis for arguing that, in the wake of Kallmann's milestone history of 1960, the story of Canadian music (as told in textbooks) seemed to focus increasingly on elite classical music composition, often with little about social or educational contexts or about the many culturally specific traditions or commercial genres that flourished in our country, even less about economics or intercultural exchange. ${ }^{2}$ That narrative has changed substantially since the late 1980 os, perhaps reflecting musical practice itself that began to move more fluidly across genres and cultural references. In about thirty years, we moved quickly from narratives of excription to ones that attempted greater inclusivity. As a corpus, post-199o studies of Canadian music included reference to more genres, more ethnicities, more locally specific traditions, and they were more often nuanced by considerations of gender and class. The most ambitious project of the latter all-encompassing, inclusive sort is Elaine Keillor's Music in Canada: Capturing Landscape and Diversity (2006). Diversity and hybridity seem to have an allure that many have quite rapidly embraced as a hallmark of Canadian cultural identity. While one might contend that the Canadian populace has rapidly diversified with extensive late twentieth-century immigration, that argument is not a compelling explanation of the scholarly turn given the many earlier waves of immigration. Who, I wonder, finds their sense of being in narratives of diversity? Are we mirroring to a large extent the governmental narrative of "multiculturalism" or the more insidious image of Canada as "peacemaker" that Paulette Regan critiques so cogently in her important book Unsettling the Settler Within (2009)? Or are we reflecting how art-making (including music) expresses the challenges of living with labels such as "minority" or "immigrant"? At some level, I feel we now have a truer idea of what music in Canada is, and yet at the same time the critiques of multiculturalism that have emerged in other disciplines, and more recently the cogent analyses of settler colonialism in Indigenous studies, have not yet been "stories" that many music scholars have bathed in. My questions here are, first, what factors led to the rapid embrace of diversity 3 in Canadian music scholarship, and second, how can we get beyond a simple "we are the world" narrative to understand the politically laden aesthetic processes that inhere in performance?

Others have asked how music scholars have been complicit with the increasingly neoliberal values of governments and public institutions in Canada. To what extent is Canadian music scholarship still caught up with nationalizing our culture? What do we commemorate? Who among us is looking to identify defining historical moments as historian Jonathan Vance (2009) has done in a recent national overview of Canadian culture, and how are those points of time defined differently by different people who live on Canadian land, who have moved to Canadian land, or been removed from their land in

2 See Diamond 1994 for an expanded published version of this paper.

3 Of course, there is always resistance to new narratives at the same time. 
our country? How do our "ways of history"4 construct individual and public memory? What about ethnically specific narratives? Do they convey the permeability of cultures without either damaging roots or effacing routes? What do the discourses of difference say about "how the local should sound" (Ochoa Gautier 2014, 8) in the minds and hearts of different citizens?

Of course, one factor that contributed to the rapid rise of a diversity narrative was change within the subfields of music scholarship more generally in the final decades of the twentieth century. Several academic organizations to which music scholars belonged were either created (e.g., IASPM-Canada 1983) or reorganized to become more research-oriented during the 1970 s and through the 1980s. Traditional music scholars as well as traditional singers/players had been organized since the 1950 s but created a journal in 1973 (Canadian Folk Music Journal) and renamed it in 1996 (Canadian Journal of Traditional Music). Folklorists established the Folklore Studies Association of Canada in 1976, and a journal (Canadian Folklore Canadien) followed in 1979. The Canadian Association of University Schools of Music started a research journal in 1981 and changed its name to the Canadian University Music Review in 1989. It is interesting that three journals again changed name and focus around the millennium, creating the current roster of FSAC's Ethnologies (1998-), CUMS (now MusCan)'s Intersections (2006-), and CSTM's MUSICultures (2009-). All have titles that avoid mentioning "Canada" and imply broad cultural approaches perhaps with less emphasis on creative objects such as pieces of music. Music scholarship, then, was organized along the vaguely generic categories of popular/traditional music, and (mostly) classical music. But the shifts in publication names are symptomatic of angst among music scholars in Canada about the dimensions of their work and the extent to which they focus on Canada or on the world.

Perhaps more significant is the fact that these academic organizations brought interdisciplinarity and public-sector knowledge into Canadian music scholarship in a major way. Not surprisingly, in the past two decades Canadian music scholarship is increasingly enriched by both interdisciplinary and cross-sector dialogue. Folklorists (Philip Hiscock, Pauline Greenhill, Richard MacKinnon, Ron Labelle, and Anna Guigné, to name only a few), sociologists (such as Line Grenier or Martin Lussier), cultural theorists (such as Will Straw), and historians (including, for example, Ian McKay, Ryan Edwardson, and Jeff Webb) have all reframed music scholarship in productive ways. So too have practitioners, particularly in the field of popular music where academic volumes by Lloyd Whitesell, William Echard, and Christopher Macdonald, for example, now sit beside books by Dave Bidini, Ritchie Yorke, or Michael Barclay. Popular music is undoubtedly the subfield of Canadian music scholarship that is the most extensively interdisciplinary. In my view, what is underdeveloped thus far is a serious debate about the potentially fruitful disjunctures and complementarities of these differently positioned studies.

4 "Ways of history" is the phrase used by Peter Nabokov (2002) in relation to Native American concepts of history. 
Arguably another factor that helped shift many toward narratives of diversity was an old preoccupation in Canadian studies: the allure of contrasting Canada with "elsewhere" has most often looked to either the "old country" or the United States. While older tiers of Canadian music scholarship often used comparison in hopes of defining a distinctive national music, more recent scholars have looked at contrasts in institutional and intellectual processes, and they have often broadened the range of national reference points. James Robbins (1990), for instance, compared Canada and the Caribbean's cultural relationship to that of the United States. Canadian-U.S. contrasts persisted in my own work (Diamond 2006) when I wrote an article for the fiftieth anniversary of the Society for Ethnomusicology, where I suggested Canada's intellectual traditions might differ from those of the United States in that we were more able to live with the "fragility of consensus." Comparison is also evident in Kip Pegley's (2008) contrasting of different national music video structures, primarily MTV and MuchMusic, where her meticulous documentation of content, presentation, and video flow offered support for Harold Innis's contention that Canada is more aware of geography, the United States of temporality. She extended her study to Finland, however, presenting a fresh look at national comparison that is less binarized. How do these stories of "us" and "elsewhere" continue to nurture us?

I suggest that comparisons with elsewhere have been further enriched, complicated, and localized by close attention to region, on one hand, and diaspora, on another. Some have suggested that the proximity of a superpower south of our borders have led many to write narratives of deficiency (see, for example, Vance 2009, vii). Related, but shaped by other factors, many of which are specific to different regions, ethnicities, or other cultural groups, are narratives of loss. I have become keenly aware of a couple of these. Historian Jerry Bannister (2002) has suggested that in Newfoundland and Labrador a preoccupation with "loss" replaced a narrative of resilience because of the accumulation of events in the second half of the twentieth century when Newfoundlanders lost their country and subsequently a way of life, when many outports were relocated, when the cod fishery moratorium was declared in 1992, and when tragedies of enormous proportions such as the sinking of the Ocean Ranger (1982) demoralized the community. The arts, and music in particular, played major roles in articulating responses to loss, offering social critique, or aesthetic pleasure that was so essential for sustainability. In spite of greater economic prosperity in Newfoundland and Labrador at present, the narratives of loss are still strong for some but are now rearticulated in many different projects oriented toward preserving, reviving, and re-inflecting public memory. These range from such things as fictional and theatrical accounts of historical moments and public figures, to revivals of traditions such as mummering and annual commemorations of culture-bearers.

A second social sphere where I am poignantly aware of narratives of loss is in Aboriginal communities that have used expressive cultures to survive the 
slow violence 5 of colonialism in its many assimilationist and genocidal guises. Music has been a vehicle of revisionist history and personal or collective healing. Contemporary Aboriginal resurgence ${ }^{6}$ is gaining strength and creative energy, in both very public movements such as Idle no $\mathrm{More}^{7}$ and in many that don't garner media attention.

How has the new attention to diversity shifted the scholarship on individuals? What are the pleasures, uses, and values of celebratory narratives of distinguished individuals, or reflective narratives by such individuals? Do we pay more attention to stories of the less celebrated? Have we turned more to characterizing and querying collectives, and which collectives would those be? I would argue that the last twenty years or so have seen a huge increase in biography and other kinds of social or musical analysis of the work of individuals (e.g., Keillor 1994; Quigley 1995; Elliott and Smith 2001; Jessup, Nurse, and Smith, 2008; Macdonald 2009; Whitesell, 2008; Echard 2005; Elliott, Salis, and DeLong, 2011; Kallmann 2013). Autobiographies have also abounded (see, e.g., Beckwith 2012; Young 2012; Doyle 2014). Since the renaming of the journal Intersections (formerly the Canadian University Music Review), Canadian musicians featured in articles have included Glenn Gould, Murray Schafer, Anne Eggleston, and Linda Bouchard. There is a profound asymmetry in the proportion of attention that celebrity artists such as Glenn Gould receives (with seventy pages of entries in the Books section of www.amazon.ca), or k.d. lang (who garners eleven pages on the same site). Many of the academic studies (like the more populist publications) are celebratory, and while the majority feature prominent classical composers, songwriters, or popular music performers, there are books about traditional musicians such as Emile Benoit and collectors such as Marius Barbeau among them. Furthermore, there are narratives of relating to the nature of memory (Elliott and Smith 2001), the impact of displacement (Elliott, Sallis, and DeLong, 2011), the force that both political and cultural institutions had on individual lives (Beckwith 2012; Jessup, Nurse, and Smith, 2008), and the way that world view shaped compositional process (Quigley 1995). There are also more stories of the less celebrated and, especially in Aboriginal studies, an increase in interviews, both in print and online (see Keillor's online projects, 2006, 2007; Hoefnagels and Diamond 2012). As Kaley Mason argued in an important article on life history in the Canadian context, we need to learn about "how people weave music in and out of the social fabric of individual and collective oral histories" $(2007,94)$. In other words, Canadian scholarship has looked to individual lives, in many cases, to explore broader

5 A term that I borrow from ecologist Rob Nixon (2011) who interrelates the toll of poverty, colonialism, and environmental degradation.

6 Resurgence is a term that Anishnabe writer and scholar Leanne Simpson has created and theorized in several recent books.

7 A movement that brought Aboriginal groups and settler allies together in peaceful assertions for justice and equality in the face of government inaction on Aboriginal health, housing, missing and murdered Aboriginal women, and environmental degradation. The movement coincided with and, in part coalesced, around Theresa Spence's fast for her people and her call to meet with Prime Minister Harper. Writing, poetry, and art associated with the Idle No More movement was subsequently published by The Kino-nda-niimi Collective (2014). 
social processes as it has in the discipline of ethnomusicology more generally (see, for example, Muller 2011; Feld 2012; and Guilbault 2014).

An important question is whether certain types of music are particularly able to accommodate diversity and serve as socially engaged platforms that are more conscious of their inevitable more-than-aesthetic positioning. A genre dear to Carl Morey's heart, opera, has proven to be one instance. Morey's numerous contributions to Opera Canada continue to inspire new perspectives on what many might regard as mainstream Canadian opera. When my peers and I studied Canadian music with Professor Morey some decades ago, however, I doubt that any of us would have predicted the extent to which Indigenous creators all over the world would gravitate to this genre, appropriating it as an apt vehicle to present colonial and inter-Indigenous relationships, as the contributors to Opera Indigene (Karantonis and Robinson 2010) demonstrate. Several Canadian contributions to Opera Indigene include chapters by co-editor Dylan Robinson (with responses by Aboriginal cultural creators and mobilizers Marion Newman, Cathi Charles Wherry, and Lorna Williams), Mary I. Ingraham, Alison Greene, Colleen L. Renihan, Robin Elliott, and myself. The very diversity of themes and approaches, from Ingraham's emphasis on citizenship, to questions of genre raised by Renihan and Elliott, to explorations of cross-cultural collaboration in Robinson and my work reorient opera studies in Canada to some extent.

\section{TOWARD New Narratives}

From my perspective, one of the most encouraging directions in Canadian music studies is that they are not as singular as they once were. Many are bridging the research-practice divide to engage cultural actors in different roles (creators, performers, policy-makers, scholars). Many are crossing disciplines and engaging in dialogue with colleagues in fields such as medicine, law, and cognitive sciences, fields that might some decades ago be thought to have little common ground with music. Many are seeking to have an impact beyond the world of academic publishing (print, audio, digital), in the realm of cultural policy, or in the development of activist alliances and networks for social transformation. Many are starting to move beyond the facts of cultural diversity and the observation of transcultural or generic hybridity to take on the challenges of autonomous difference and productive (hopefully non-violent) conflict that are at the heart of vibrant contemporary cultures.

There are many hopeful indications that we are already taking on issues of social import. One might look at research centres for an indication of Canadian music research strengths and cutting edge directions. The McGill Institute for the Study of Canada, directed by Will Straw, has studied the structures, histories, and ideologies of cultural industries, the culture of cities, public memory in the digital era, and Canadian film. Technological change and mediation are central to the missions of the Centre for Interdisciplinary Research in Music, Media, and Technology (CIRMMT) at McGill, and Advancing Interdisciplinary Research on Singing (AIRS), as well as CRC Paul Théberge’s work 
at Carleton University. Arguably, each of these is oriented to different questions and their consequent narratives, sometimes focusing on technological potential, others on the layers of social meaning, impact, and shifts in creative process that technological mediation creates. New projects of public memory creation in both pre-digital and digital media are part of the mandates of the Centre for Ethnomusicology (University of Alberta) and Research Centre for Music, Media, and Place (Memorial University), centres that also prioritize community collaboration and participatory research. Research creation has been explicitly or implicitly central to the work of several of these centres but has been theorized most extensively at LARC, where Director Serge Lacasse and Sophie Stevance have worked on what Lacasse has termed "vocal staging," among other things, most recently with the innovative Inuit artist Tanya Tagaq. Implicitly, embodiment and live performance are necessarily aspects of media research, but attention to the voice is particularly central to their work, as well as that of the Advancing Interdisciplinary Research on Singing (AIRS) project, directed by psychology professor Annabel Cohen and based at the University of Prince Edward Island. The political and socially productive processes of music-making are explored in AIRS, as well as in two back-to-back, large-scale inter-university projects (Improvisation, Community, and Social Practice [ICASP] and the International Institute for Critical Studies in Improvisation [IICSI]) directed by Ajay Heble and based at the University of Guelph that look at improvisation as social process. Among the many publications resulting from Heble's initiatives is the journal Critical Studies in Improvisation / Etudes critiques en improvisation. Aboriginal research centres-among them the Centre for Indigenous Research, Culture, Language, and Education (CIRCLE) at Carleton University, which has been directed by both Elaine Keillor and Anna Hoefnagels-often include music and other arts-based scholars. Such institutes are leading the way in generating Aboriginal-centred critiques of settler colonialism that will be essential for ecological and social sustainability. The growth of ecomusicology, first at Simon Fraser University (with initiatives by Barry Truax and Hildegarde Westercamp) and Concordia (particularly in work by Andra McCartney), but now at several other schools, is a significant node in dialogue with Aboriginal studies. Of course dozens of other individual projects lead us to new ways of thinking about music. Consider Norma Coates and Jim Deaville's work on television or Kip Pegley's ongoing cognitive and ethnographic work with war veterans using sound to help heal post-traumatic stress disorder. And dozens do significant work that changes music in Canada even while they research elsewhere.

While these large-scale and sustained research initiatives indicate cuttingedge directions in Canadian music research, some of the most innovative directions are evident in the work of young scholars. They are contributing to a much more nuanced understanding of the narratives that shape the simultaneous or sequential meanings that music inevitably has for creators, performers, and listeners. Recent work has focused less on processes of nationalization than on processes of localization and shifting definitions of (musical) ethnic or gender identity. Examples at my own university are studies that localize 
Mi'kmaq powwow practices by Janice Tulk (2008) or Inuit Christian worship by Mary Piercey (2013), or Evelyn Osborne's (2012) unpacking of Irishness as it was defined differently in three different decades in Newfoundland traditional music circles. Music as a mode of resistance to social dictates has been a popular theme among twenty-first-century scholars. For instance, a themed volume of MUSICultures, emanating from a joint meeting of IASPM-Canada and the Canadian Society for Traditional Music in 2010, was titled "Spaces of Violence, Signs of Resistance." Dissertations at my own university by Judith Klassen (2008) on diasporic Mennonite resistance to conservative orthodoxy, and by Ian Hayes (2014) on controversies about technological mediation in Cape Breton demonstrate how controversy is often, perhaps inevitably, at the heart of musical practice. Marion MacLeod (2013) has explored musical irony as a mode of double address that distinguishes insiders and outsiders, those in the know and those who don't get the allusions. Closely related are important studies by Canadians teaching in the United Kingdom and the United States, particularly Byron Dueck's important (2013) book on Métis musical imaginaries, one that sheds light on the way music mediates "public intimacy" in Aboriginal-settler contexts, or Christopher Scales's (2012) study of the Aboriginal recording industry. Topics that span Canada and other countries (e.g., Indigenous modernities, Atlantic roots and routes) have been addressed in several recent special topics issues of MUSICultures. Transnational and intercultural processes have been a significant focus in studies by graduate students and faculty in the twenty-first century, often getting beyond description to look at music as a microcosm of power-laden relationships that reflect colonial traces of racial and class constructs. Others studies are addressing histories of institutions (building on earlier studies by Will Straw, mentioned earlier, as well as Schabas and Morey's 2000 history of the Canadian opera company, or Robin Elliott's 1997 history of the Women's Musical Club of Toronto).

Much of this research recognizes the multiplicity of meanings that music inevitably generates and its unique capacity to be a space for contested points of view, multiple narratives, and different aesthetically defined politics. Canada is fertile ground for such studies. If, as I argued a few years ago (Diamond 2006), intellectual formation in Canada is influenced by our capacity to accept the "fragility of consensus" to a larger extent than many other affluent nations, how might we cherish and cultivate such a capacity so that Canadian music study could play a significant role in defining and modelling social encounter, demonstrating how sovereign aesthetics might interact, and building cultural alliances in the twenty-first century?

\section{REFERENCES}

Bannister, Jerry. 2002. "Making History: Cultural Memory in 2oth-Century Newfoundland." Newfoundland Studies 18 (2): 175-94.

Beckwith, John. 2012. Unheard Of: Memoirs of a Canadian Composer. Waterloo, ON: Wilfrid Laurier University Press. 
Diamond, Beverley. 1994. "Narratives in Canadian Music History." In Canadian Music: Issues of Hegemony and Identity, ed. Beverley Diamond and Robert Witmer, 139-72. Toronto: Canadian Scholars' Press.

- 2006. "Canadian Reflections on Palindromes, Inversions, and Other Challenges to Ethnomusicology's Coherence." Ethnomusicology 49 (3): 324-36.

Doyle, Alan. 2014. Where I Belong. Toronto: Doubleday.

Dueck, Byron. 2013. Musical Intimacies and Indigenous Imaginaries: Aboriginal Music and Dance in Public Performance. New York: Oxford University Press.

Echard, William. 2005. Neil Young and the Poetics of Energy. Bloomington: Indiana University Press.

Elliott, Robin. 1997. Counterpoint to a City. Toronto: ECW.

Elliott, Robin, and Gordon E. Smith, eds. 2001. Istvan Anhalt: Pathways and Memory. Montreal and Kingston: McGill-Queen's University Press.

Elliott, Robin, Friedemann Sallis, and Kenneth DeLong, eds. 2011. Centres and Peripheries. Roots and Exile (Waterloo, ON: Wilfrid Laurier University Press.

Feld, Steven. 2012. Jazz Cosmopolitanism in Accra. Durham, NC: Duke University Press.

Guilbault, Jocelyne. 2014. Roy Cape: A Life on the Calypso and Soca Bandstand. Durham, NC: Duke University Press.

Hayes, Ian. 2014. "It's a balancing act. That's the secret to making this music fit today': Negotiating Professional and Vernacular Boundaries in the Cape Breton Fiddling Tradition." PhD diss., Memorial University, St. John's.

Hoefnagels, Anna, and Beverley Diamond, eds. 2012. Aboriginal Music in Contemporary Canada: Echoes and Exchanges. Montreal and Kingston: McGill-Queen's University Press.

Jessup, Lynda, Andrew Nurse, and Gordon E. Smith, eds. 2008. Around and about Marius Barbeau: Modelling Twentieth-Century Culture. Mercury Series. Ottawa: Canadian Museum of Civilization.

Kallmann, Helmut. 1960. A History of Music in Canada 1534-1914. Toronto: University of Toronto Press.

-2013. Mapping Canada's Music: Selected Writings of Helmut Kallmann, ed. John Beckwith and Robin Elliott. Waterloo, ON: Wilfrid Laurier University Press.

Karantonis, Pamela, and Dylan Robinson, eds. 2010. Opera Indigène. Farnham, UK: Ashgate.

Keillor, Elaine. 1994. John Weinzweig and His Music: The Radical Romantic of Canada. Metuchen: Scarecrow.

-2005. Native Drums, www.native-drums.ca.

- 2006. Music in Canada: Capturing Landscape and Diversity. Montreal and Kingston: McGill-Queen's University Press.

2007. Native Dance, www.native-dance.ca.

Kina-nda-niimi Collective. 2014. The Winter We Danced: Voices from the Past, the Future, and the Idle No More Movement. Winnipeg: Arp Books. 
Klassen, Judith. 2008. "Encoding Song: Faithful Defiance in Mexican Mennonite Music Making." PhD diss., Memorial University, St. John's.

Macdonald, Christopher J. 2009. Rush, Rock Music and the Middle Class: Dreaming in Middletown. Bloomington: Indiana University Press.

MacLeod, Marion. 2013. "Raising the Bar: The Reciprocal Roles and Deviant Distinctions of Music and Alcohol in Acadiana." PhD Diss., Memorial University, St. John's.

Marsh, Charity, and Gordon E. Smith, eds. 2011. "Spaces of Violence: Signs of Resistance." Thematic Issue, MUSICultures 38.

Mason, Kaley. 2007. "Situating Musical Lives in Multiethnic Canada: Listening for the Non-Western 'I."' In Folk Music, Traditional Music, Ethnomusicology: Canadian Perspectives, Past and Present, ed. Anna Hoefnagels and Gordon E. Smith, 94-101. Newcastle, UK: Cambridge Scholars.

Morey, Carl. 1997. Music in Canada: A Research and Information Guide. New York: Garland.

Muller, Carol. 2011. Musical Echoes: South African Women Thinking in Jazz. Durham, NC: Duke University Press.

Nabokov, Peter. 2002. A Forest of Time: American Indian Ways of History. Cambridge: Cambridge University Press.

Nixon, Rob. 2011. Slow Violence and the Environmentalism of the Poor. Cambridge, MA: Harvard University Press.

Ochoa Gautier, Ana Maria. 2014. Aurality: Listening and Knowledge in 19thCentury Colombia. Durham, NC: Duke University Press.

Osborne, Evelyne. 2012. "The Most (Imagined) Irish Place in the World? The Interaction between Irish and Newfoundland Musicians, Mass Media and the Contruction of Musical Senses of Place." PhD diss., Memorial University, St. John's.

Pegley, Kip. 2008. Coming to You Wherever You Are: MuchMusic, MTV and Youth Identities. Middletown, CT: Wesleyan University Press.

Piercey, Mary. 2013. “'Inulariuyunga Imngirnik Quvigiyaqaqtunga!'-'I’m a real Inuk. I love to sing!' Interactions between Music, Inummariit, and Belief in an Inuit Community since Resettlement." PhD diss., Memorial University, St. John's.

Quigley, Colin. 1995. Music from the Heart. Athens: University of Georgia Press. Regan, Paulette. 2009. Unsettling the Settler Within. Vancouver: University of British Columbia Press.

Robbins, James. 1990. "What Can We Learn When They Sing, Eh? Ethnomusicology in the American State of Canada." In Ethnomusicology in Can$a d a$, ed. Robert Witmer, 47-56. CanMus Docs 05. Toronto: Institute for Canadian Music.

Scales, Christopher. 2012. Powwow Music and the Aboriginal Recording Industry on the Northern Plains. Durham, NC: Duke University Press.

Schabas, Ezra, and Carl Morey. 200o. Opera Viva: Canadian Opera Company, the First Fifty Years. Toronto: Dundurn.

Simpson, Audra, and Andrea Smith, eds. 2014. Theorizing Native Studies. Durham, NC: Duke University Press. 
Simpson, Leanne. 2013. The Gift Is in the Making: Anishnaabeg Stories. Winnipeg: High Waters Press.

Tulk, Janice. 2008. “'Our Strength Is Ourselves': Identity, Status and Cultural Revitalization among the Mi'kmaq in Newfoundland." PhD diss., Memorial University, St. John's.

Vance, Jonathan. 2009. A History of Canadian Culture. New York: Oxford University Press.

Whitesell, Lloyd. 2008. The Music of Joni Mitchell. New York: Oxford University Press.

Young, Neil. 2012. Waging Heavy Peace: A Hippie Dream. New York: Blue Rider.

\begin{abstract}
This article is a reflection on how narratives of Canadian music scholarship have shifted since the late 1980s, generally moving toward an array of "diversity narratives." It questions how government policy, academic institution building, increased interdisciplinarity, new configurations of individual and collective experience, and new regional or nationalist discourses have played a role in this shift. It suggests that Canadians may be particularly well poised to lead in the study of how multiple narratives and "sovereign aesthetics" can coexist.
\end{abstract}

\title{
RÉSUMÉ
}

Cet article propose une réflexion sur les transformations des récits des chercheurs en musique canadienne au cours des années 1980, transformations qui ont généralement mené à un récit davantage centré sur les diversités. On y examine comment les politiques gouvernementales, la construction d'institutions universitaires, l'augmentation de l'interdisciplinarité, les nouveaux modèles d'expérience individuelle et collective et de nouveaux discours identitaires régionaux et nationaux ont joué un rôle dans ces transformations. On avance que les Canadiens sont sans doute particulièrement bien placés pour montrer la voie dans l'étude de la façon dont plusieurs récits et «esthétiques souveraines » peuvent coexister. 